http://dx.doi.org/10.12775/szhf.2016.010

Anna Markwart

Uniwersytet Jagielloński, KRaków, Polska

MARKWART.ANNA@GMAIL.COM

\title{
Adam Smith o instynktach i popędach
}

Adam Smith (1723-1790) w swojej filozofii podejmował wiele zagadnień: poczynając od rozważań poświęconych teorii moralnej, których wykład przedstawił w Teorii uczuć moralnych, poprzez zagadnienia dotyczące piękna, literatury, retoryki, uwagi o starożytnej fizyce, logice i astronomii, kończąc na dziele stanowiącym podwaliny dla późniejszej ekonomii klasycznej: Badaniach nad natura i przyczynami bogactwa narodów. Debata naukowa skupiająca się na myśli Smitha jest wciąż żywa - najczęściej roztrząsane są niuanse jego poglądów etycznych lub ekonomicznych, ale sięga się także do innych jego tekstów. Wciąż dyskutowany jest również tzw. Adam Smith Problem ${ }^{1}$, do-

${ }^{1}$ Por:: David Daiches Raphael, Alec L. Macfie, Introduction, [w:] A. Smith, The Theory of Moral Sentiments (red. tenże), Liberty Fund, Indianapolis 1982, s. 20-25; Knud Haakonssen, Donald Winch, The Legacy of Adam Smith, [w:] Knud Haakonssen (red.), The Cambridge Companion to Adam Smith, Cambridge University Press, New York 2006, s. 369; Leonidas Montes, Adam Smith in Context. A Critical Reassessment of some Central Components of His Thought, Palgrave Macmillan, 2004, s. 15-32; Richard Teichgraeber III, Rethinking das Adam Smith Problem, „Journal of British Studies”, Vol. 20, nr 2 (wiosna 1981), s. 106; F. FormanBarzilai, Adam Smith and the Circles of Sympathy. Cosmopolitanism and Moral Theory, Cambridge University Press, Cambridge 2011, s. 29-30; James R. Otteson, Adam Smith's Marketplace of Life, Cambridge University Press, Cambridge 2002, s. 134; Maria Pia Paganelli, Theory of Moral Sentiments 1759 vs. Theory of Moral Sentiments 1790: a Change of Mind or a Change in Constraint?, [w:] Wade L. Robison, David B. Suits, New Essays on Adam Smith's Moral Philosophy, Rit Press, Rochester, New York 2012, s. 35; Dogan Göçmen, The "Adam Smith Problem" and Adam Smith's Utopia, [w:] New Essays on Adam Smith's Moral Philosophy, s. 45. 
tyczący kwestii wewnętrznej spójności myśli filozofa, najczęściej w kontekście porównywania charakterystyk człowieka leżących u podłoża Teorii uczuć moralnych i Bogactwa narodów.

W obu tych pracach autor pojmował człowieka jako istotę społeczną. Twierdził, że moralności, wydawania sądów etycznych, oceniania własnego postępowania, dostrzegania piękna i brzydoty uczymy się (a następnie umiejętności te doskonalimy) dopiero dzięki kontaktom z innymi ludźmi. Na nasze poglądy oraz na zasady, którymi się kierujemy, istotny wpływ mają opinie i zachowanie członków rodziny, przyjaciół, grupy społecznej, do której należymy, jak również osób cieszących się autorytetem i ludzi możnych. Chociaż ostatecznie u podstaw wielu procesów opisywanych w najważniejszych pracach Smitha leżą pojedyncze ludzkie działania, nierozerwalnie są one jednak związane z wpływem społeczeństwa. Należy zarazem podkreślić, że Smith nigdy nie stworzył systematycznego i pełnego obrazu natury ludzkiej, uważa się nawet, że wyczerpujący opis natury ludzkiej uważał za niemożliwy ${ }^{2}$.

W takim obrazie brakuje jednak uwzględnienia tego, że wiele spośród działań podejmowanych przez ludzi opiera się na wrodzonych im zdolnościach i dążeniach. Smith zauważał istnienie cech i pragnień wspólnych wielu ludziom, ujmował człowieka również jako istotę biologiczną, chociaż uwagi na ten temat znajdowały się raczej na marginesie jego zainteresowań. W niniejszym artykule skupiam się na tej właśnie, bardzo rzadko podnoszonej przez badaczy myśli Smitha, kwestii, tj. na znaczeniu, jakie przypisywał pojęciom instinct $^{3}$ i appetite ${ }^{4}$. Pojawiają się one przede wszystkim w dwóch pracach: wspomnianej uprzednio Teorii uczuć moralnych oraz w eseju Of the External Senses ${ }^{5}$. Charakterystyka tych pojęć w kontekście całokształtu myśli Adama

${ }^{2}$ Pratap Bhanu Mehta, Self-Interest and Other Interests, [w:] Knud Haakonssen (red.), The Cambridge Companion to Adam Smith, s. 247-248.

${ }^{3}$ Instinct, za słownikiem Samuela Johnsona: „Pragnienie lub wstręt działające w umyśle bez udziału rozsądku czy rozważań; siła determinująca wolę bezmyślnych”, przekład własny, Samuel Johnson, A Dictionary of the English Language: in which the words are deduced from their originals, and illustrated in their different significations by examples from the best writers, Londyn 1785, t. I, s. 1054, https://archive.org/details/dictionaryofengl01johnuoft, 01.06.2014.

${ }^{4}$ Appetite, za słownikiem Samuela Johnsona: „1. Naturalne pragnienie dobra; instynkt, który nas kieruje ku poszukiwaniu przyjemności [...] 2. Pożądanie przyjemności zmysłowej [...] 3. Silne pragnienie; ochota na coś [...] 4. Przedmiot silnego pożądania [...] Głód, pragnienie jedzenia...", przekład własny, Samuel Johnson, op. cit., s. 169.

${ }^{5}$ Powstały dwie główne hipotezy dotyczące roku powstania eseju. Jedna z nich głosi, że powstał on przed 1752 rokiem, druga zaś datuje go na lata 1758-1759 (wówczas powstawały także poprawki do Teorii uczuć moralnych), więcej: K. L. Brown, Dating Adam Smith’s "Of the 
Smitha będzie stanowić, jak sądzę, cenne uzupełnienie istniejących już analiz jego filozofii. Rekonstrukcja rozważań Smitha poświęconych tym zagadnieniom pozwoli lepiej zrozumieć dynamikę relacji pomiędzy czynnikami wrodzonymi ludziom a wpływem społeczeństwa na indywidualne zachowania człowieka oraz podkreśli istotną rolę naturalnych potrzeb. Zaznaczę także inny istotny dla tych rozważań wątek, jakim jest rola społeczeństwa w kształtowaniu sposobów zaspokajania tych potrzeb oraz podkreślę zależność pomiędzy społecznym kształtowaniem moralnością a wrodzonymi elementami natury ludzkiej.

Rozważania dotyczące instynktów nie były w epoce Adama Smitha wcale rzadkie: warto przywołać choćby Thomasa Reida ${ }^{6}$, wspominającego o instynktownych zasadach ludzkiego postępowania, lorda Kamesa, którego przemyślenia nad instynktem (lub też popędem) społecznym, są niezwykle systematyczne ${ }^{7}$, Thomasa Hobbesa, w którego pismach rola appetites oraz znaczenie dążenia do samozachowania są wzajemnie skorelowane (w Lewiatanie pojawia się pojęcie appetites ${ }^{8}$, w Elementach filozofii zaś łacińskie appeti-

External Senses”, „Journal of the History of Ideas”, Vol. 53, nr 2 (kwiecień-lipiec 1992), s. 333-337; William P. D. Wightman, Introduction, [w:] A. Smith, Of the External Senses, [w:] tenże, Essays on Philosophical Subjects, The Glasgow Edition of the Works and Correspondence of Adam Smith, Liberty Fund, Indianapolis 1982, s. 133.

${ }^{6}$ Por.: T. Reid, Rozważania o władzach poznawczych człowieka, Warszawa 1975. Warto wspomnieć, że Reid objął po Smithcie katedrę w Glasgow w 1764 roku.

${ }^{7}$ Ch. Berry, Social Theory of the Scottish Enlightenment, Edynburg 1997, s. 25.

${ }^{8}$ Por.: T. Hobbes, Leviathan, http://lf-oll.s3.amazonaws.com/titles/585/Hobbes_0051-03_ EBk_v6.0.pdf, 10.05.2014. Zdaniem Hobbesa dążenie w organizmie „gdy jest zwrócone ku czemuś, co je wywołuje, nazywa się APETYTEM, czyli POŻĄDANIEM [...] Gdy zaś dążenie jest odwrócone od czegoś, nazywa się zazwyczaj AWERSJĄ lub wstrętem [...] Spośród apetytów i awersji niektóre są ludziom wrodzone; na przykład: pożądanie pożywienia, dążenie do usunięcia wydalin (które można również, i to bardziej właściwie, nazywać awersjami w stosunku do czegoś, co ludzie czują w swych ciałach) i jeszcze pewna ilość pożądań, lecz niewielka. Reszta, pożądania pewnych szczególnych rzeczy określonych, to dążenia, które powstają z doświadczenia i wypróbowania ich skutków na sobie samym lub na innych ludziach" (T. Hobbes, Lewiatan czyli materia, forma i władza państwa kościelnego i świeckiego, przeł. C. Znamierowski, Warszawa 2009, I.6., s. 128-129). W jego myśli rola pojęcia appetites w dążeniu do samozachowania jest dużo większa, niż w teorii Adama Smitha. Zdaniem Paula Hurleya można wyróżnić dwa główne rodzaje appetites obecnych w teorii Hobbes’a (por:: Eugene Heath, Mandeville's Bewitching Engine of Praise, „History of Philosophy Quarterly”, Vol. 15, nr 2, kwiecień 1998): ruch w ciele oraz postrzeganie przedmiotów jako potencjalnie przyjemnych lub odpychających, przy czym sam filozof odróżniał pożądanie i wstręt od przyjemności i przykrości, za kryterium uznając czas: te pierwsze są antycypacją możliwej przyjemności lub przykrości związanej z określonym doznaniem (T. Hobbes, O człowieku, [w:] Elementy filozo- 
tio ${ }^{9}$ ), czy Bernarda Mandeville’a ${ }^{10}$, który pisał o zaspokajaniu popędów przez ludzi, lub wreszcie Davida Hume’a, podkreślającego znaczenie afektywnego aspektu ludzkiego doświadczenia. Chociaż nie wszystkie uwagi Adama Smitha w odniesieniu do tego zagadnienia były przełomowe, a esej poświęcony zmysłom zewnętrznym jest najczęściej pomijany przez badaczy jego myśli, warto odnotować, że dostrzegając istnienie instynktów i popędów, Smith podkreślał, że zachowania człowieka często biorą początek we wrodzonych potrzebach.

Piszący w tym samym niemal czasie, co Adam Smith, David Hume, uwzględniał w swych rozważaniach rolę instynktów oraz pragnien i podobnie jak Hobbes łączył przyjemność $\mathrm{z}$ dobrem, a zło z bólem, jednakże inaczej niż on rozumiał pojęcia dobra i zła. Filozof z Edynburga uznawał, że tak jak dobro może wzbudzać pragnienia, tak i pragnienia mogą prowadzić do dobra ${ }^{11}$. Sposób, w jaki Hume pisał o instynkcie i popędach (appetites), zapowiada rozważania Smitha. Autor Traktatu o naturze ludzkiej wspomina o tym, że „doznania pragnienia płciowego i głodu zawsze wywołują w nas ideę tych przedmiotów swoistych, które je mogą zaspokajać" ${ }^{2}$. Hume dzielił pożądania na wypływające $\mathrm{z}$ niepoddającego się dalszej eksplikacji ${ }^{13}$ naturalnego instynktu i na oparte na przyjemności i przykrości ${ }^{14}$. Do tych instynktownych zaliczał „...̇zyczliwość, resentyment, umiłowanie życia, dobroć dla dzieci [...] i kilka popędów cielesnych, takich jak głód czy pożądanie"15. Naturalne silne uczucia żywione wobec potomstwa nie są charakterystyczne jedynie dla ludzi - podobnie reagują zwierzęta ${ }^{16}$. Mówiąc o appetites, bardzo często odwoływał się do kwestii popędu seksualnego czy głodu, jednak inaczej niż Hobbes, Hume nie wpisywał instynktu samozachowawczego w uczucia

fii, Kraków 1956, r. XI, s. 123-124). Takie postrzeganie pożądania i wstrętu musi prowadzić do relatywizmu (P. Hurley, The Many Appetites of Thomas Hobbes, s. 395), odwoływanie się do appetites służy zatem innemu celowi, niż występuje to w teorii Adama Smitha.

${ }_{9}$ Por.: Thomas Hobbes, Opera Philosophica, https://archive.org/stream/operaphilosophi00 molegoog\#page/n6/mode/2up, 12.05.2014.

${ }^{10}$ Por.: Eugene Heath, Mandeville's Bewitching Engine of Praise, „History of Philosophy Quarterly", Vol. 15, nr 2 (kwiecień 1998).

${ }^{11}$ Por.: E. B. McGilvary, Altruism In Hume's Treatise, „The Philosophical Review”, vol. 12, nr 3, maj 1903, s. 282.

${ }_{12}$ D. Hume, Traktat o naturze ludzkiej, Warszawa 2005, s. 367.

13 Tamże, s. 513.

${ }^{14}$ Por.: Evander B. McGilvary, Altruism..., s. 276; David Hume, Traktat..., s. 513-514.

${ }^{15}$ E. B. McGilvary, Altruism..., s. 277.

${ }^{16}$ D. Hume, Traktat..., s. 472. 
egoistyczne. Mimo to, podobnie jak Smith, traktował troskę o własny interes jako niezwykle istotny motyw postępowania ludzi, chociaż jego poglądy dotyczące samobójstwa ${ }^{17}$ różnią się od tych prezentowanych przez Smitha. Należy jednak pamiętać, że uwagi obu filozofów poświęcone temu zagadnieniu stanowią marginalny aspekt ich myśli.

Kluczowe znaczenie dla rekonstrukcji koncepcji instynktów w filozofii Smitha ma jego esej Of the External Senses, poświęcony problematyce zmysłów wzroku, słuchu, dotyku, zapachu, smaku. Przedstawiając w nim swoją analizę, obejmującą wszystkie zmysły, Adam Smith odwoływał się do poglądów zaprezentowanych przez George’a Berkeleya w Próbie stworzenia nowej teorii widzenia, jednoznacznie wyrażając w swoim eseju podziw dla jego dokonań ${ }^{18}$. Obaj filozofowie ${ }^{19}$ rozważali, czy przedmioty wzroku i dotyku mogą być skorelowane $\mathrm{w}$ taki sposób, że wiążemy je ze sobą instynktownie, przy czym, w przeciwieństwie do Berkeleya, Smith twierdził, że jest możliwe, aby instynkt, który nie uaktywnił się w początkowych etapach życia człowieka, uległ atrofii. Smith zauważał, że wiele gatunków zwierząt ma instynkt, pozwalający już od urodzenia - jak to się dzieje w przypadku kurcząt, które od razu odróżniają ziarno od innych przedmiotów i potrafią je wydziobywać ${ }^{20}-$ lub od momentu otworzenia oczu i uzyskania zdolności widzenia - jak dzieje się u kotów, zestawiać to, co widzą, z przedmiotami wzroku. Ta zdolność pełni ważną funkcję w kontekście ich zdolności do przetrwania.

Inaczej niż Berkeley, ujmujący człowieka przede wszystkim w perspektywie religijnej, Adam Smith łączył w swym opisie natury ludzkiej uwarunkowania biologiczne i społeczne. Twierdził, że trudno byłoby przyjąć założenie, jakoby człowiek był jedynym zwierzęciem, którego młode są pozbawione tego typu instynktu. Uważał, że długa niesamodzielność niemowląt wiąże się raczej z odgrywaniem znacznie mniejszej roli przez instynkt, niż w przypadku innych stworzeń. Zwracał uwagę, że małe dzieci, zanim nauczą się samodzielnie przemieszczać i jeść, wymagają opieki. Człowiek ma do dyspozycji dłuższy okres usamodzielniania się pod opieką innych, którzy dostarczają mu pożywienie i zapewniają bezpieczeństwo, i dopiero dzięki doświadczeniu wiąże przedmioty wzroku z przedmiotami dotyku oraz poznaje ich prze-

${ }^{17}$ D. Hume, O samobójstwie, [w:] Badania dotyczące rozumu ludzkiego, Kraków 2006.

${ }_{18}$ A. Smith, Of the External Senses..., $\$ 43$, s. 148.

${ }^{19}$ Szersze omówienie poglądów Smitha i Berkeleya dotyczących zmysłów zewnętrznych w: A. Markwart, M. Szymańska, O zmysłach i postrzeganiu - czyli czego nie wiemy o Berkeleyu, a dowiadujemy się od Smitha i vice versa, ,Filo-Sofija”, rok XII, nr 17 (2012/2), Bydgoszcz 2012.

${ }^{20}$ A. Smith, Of the External Senses..., \$70, s. 161-162. 
znaczenie $^{21}$. Natura wyposaża zwierzęta i ludzi jedynie w to, co niezbędne i przydatne, a w przypadku tych ostatnich, zbędne byłoby posiadanie od urodzenia silnie rozwiniętej umiejętności korelowania przedmiotów wzroku z przedmiotami dotyku, ponieważ nie muszą zapewniać sobie środków do samodzielnego przetrwania. Nie oznacza to jednak, że niemowlęta w ogóle pozbawione są wszelkich zachowań instynktownych ${ }^{22}$.

Według Smitha instynkt odgrywa bardzo ważną rolę w dążeniu ludzi i innych zwierząt do samozachowania. Jak zauważał, młode różnych gatunków instynktownie łączą przedmioty wzroku z przedmiotami dotyku ${ }^{23}$, dzięki czemu są w stanie rozpoznawać pokarm. Podobnie dzieje się z człowiekiem, którego popędy (appetites) wskazują drogę ku temu, co potrzebne dla przetrwania, przyjemności i dobra.

Podobnie jak nowonarodzone ptaki kierują się ku ziarnu, tak młode ssaki rodzą się wyposażone przez naturę w odruch ssania i, instynktownie, podążają ku sutkom matki - nawet, jeżeli wciąż jeszcze nie potrafią widzieć:

popęd do jedzenia sugeruje noworodkowi proces ssania, jedyny środek, dzięki któremu będzie w stanie zaspokoić swoją potrzebę. Noworodek wciąż ssie, co sugeruje mu apetyt (appetite) na jedzenie. Ssanie jest [jedynym - A. M.] sposobem, w który może zaspokoić głód. Ciągle ssie. Ssie wszystko, co podsuwa się jego ustom. Ssie nawet, gdy nie daje mu się nic do ssania, a pewna antycypacja przyjemności, którą będzie się cieszyć podczas ssania, sprawia, że znajduje przyjemność w układaniu ust w taki sposób, w jaki jedynie może doświadczyć tej rozkoszy ${ }^{24}$.

\footnotetext{
${ }^{21}$ Tamże, $\$ 74$, s. 163.

${ }^{22}$ W Teorii uczuć moralnych Adam Smith zauważył jeszcze inną, ciekawą cechę dzieci: instynktownie wierzą we wszystko, co usłyszą. Z natury człowiek okazuje się łatwowierny i zakładający prawdomówność innych. Dopiero doświadczenie sprawia, że staje się nieufny por. Adam Smith, Teoria uczuć moralnych, przeł. D. Petsch, Warszawa 1989, s. 506.

${ }^{23}$ Co ważne, rozważania Smitha odnoszą się głównie do problematyki widzenia, co zapewne bierze się nie tylko ze znaczenia tego zmysłu w życiu człowieka, ale też jest wynikiem pewnej zależności pracy Smitha od eseju Berkeleya. Zdaniem filozofa zmysły inne niż wzrok i dotyk nie sugerują nam istnienia przedmiotów zewnętrznych. Aby poczuć smak, już wcześniej rozpoznaje się kształt danego przedmiotu poprzez dotyk: w ustach. Podobnie w przypadku ciepła i zimna: ani one, ani sam smak nie są w stanie zasugerować kształtu czy rodzaju substancji przedmiotu dotyku.

${ }^{24}$ A. Smith, Of the External Senses...., $\$ 79$, s. 165, przekład własny.
} 
Nie potrzeba rozumowania ani wskazówek innych, by odnaleźć drogę do zaspokojenia podstawowych potrzeb życiowych. Smith stawiał hipotezę, że zmysłem, który prowadzi ssaki ku pokarmowi, jest węch. Pełni on w tej sytuacji dwojaką funkcję: kieruje do źródła pożywienia, a zarazem rozbudza apetyt na odpowiedni pokarm ${ }^{25}$. Zapach potęguje głód, nawet w przypadku zwierząt, które właśnie przyszły na świat i nic jeszcze nie jadły. Oznacza to, że powiązanie pomiędzy zachęcającą wonią jedzenia a wzrastającym pragnieniem spożycia go nie pojawia się na drodze doświadczenia i wiązania wrażeń zmysłowych ze sobą oraz z przyjemnością odczuwaną z jedzenia. Potrzeba zaspokojenia głodu jest silna od urodzenia i niemal automatycznie kieruje nas ku właściwemu pożywieniu.

Wiąże się z tym jedna z najciekawszych obserwacji filozofa dotycząca popędów (appetites): przekonanie, że „....wszystkie popędy, których źródłem jest pewien stan ciała, wydają się sugerować środki do ich zaspokojenia" ${ }^{26}$. Dotyczy to nie tylko jedzenia, którego przyjemny zapach wabi. Należy do nich także, na przykład, popęd seksualny, który, jak skonstatował Adam Smith: „...niemal zawsze, pojawia się na długo przed wiekiem dojrzewania”27. Można zatem postawić hipotezę, że zdaniem szkockiego filozofa, najważniejsze dla przetrwania pojedynczej istoty żywej i całego gatunku sfery: odżywianie i rozmnażanie, wiążą się z wrodzonymi ludziom instynktownymi zachowaniami. Niektórzy komentatorzy dostrzegają w tych twierdzeniach Smitha antycypację poglądów Freuda dotyczących wczesnego pojawienia się popędu seksualnego ${ }^{28}$. Popędy te odgrywają niezwykle istotną i złożoną rolę: sygnalizują konieczność podjęcia działań, sugerują, jakie powinny być to działania i wskazują obiekty, które pozwolą zaspokoić konkretną potrzebę. To, ku czemu kierują, wiąże się nie tylko z samozachowaniem jednostki czy gatunku (w wymiarze biologicznym), ale też łączy się z przyjemnością i wpływa na sferę emocjonalną.

Chociaż w Teorii uczuć moralnych pojęcia instinct oraz appetite pojawiają się przede wszystkim w kontekście zachowań społecznych i moralnych (będących głównym tematem tego dzieła), obecne są tam też nieliczne odniesienia do kwestii biologicznego przetrwania. Smith zwraca uwagę, że:

\footnotetext{
25 Tamże, $\$ 77$, s. 164.

${ }^{26}$ Tamże, $\$ 79$, s. 165.

${ }_{27}$ Tamże, $\$ 79$, s. 165, przekład własny.

${ }^{28}$ Tamże, przypis 33, s. 165.
} 
zachowanie zdrowego stanu ciała zdaje się być pierwszym celem, jaki zaleca natura trosce każdej jednostki. Doznania ${ }^{29}$ głodu i pragnienia, miłe i przykre uczucia przyjemności i cierpienia, ciepła i zimna i tym podobnych można rozważać jako pouczenia głosu samej Natury wskazującej człowiekowi, co powinien wybrać, a czego unikać, aby osiągnąć ten cel. Pierwsze wskazania, które otrzymuje od tych, których pieczy powierzono go w dzieciństwie skłaniają go na ogół do tego samego zamierzenia. Ich głównym celem jest nauczyć go, jak unikać szkodliwych sposobów postępowania ${ }^{30}$.

Instynkt przetrwania sprawia, że szukamy tego, co przyjemne i potencjalnie dobre, a jednocześnie unikamy możliwych zagrożeń. Dzięki zmysłom, uczymy się rozpoznawać szkodliwe przedmioty oraz stronić od tego, co może nas skrzywdzić. Jednym z mechanizmów ostrzegających jest język natury, przedstawiony w Of the External Senses na podstawie Berkeleyowskiej ${ }^{31}$ koncepcji języka Stwórcy natury. Obaj myśliciele zakładali, że wiążąc przedmioty wzroku z przedmiotami dotyku i obrazując prawa natury, język pozwala człowiekowi rozróżniać to, co może przyczynić się do jego dobra oraz unikać tego, co potencjalnie jest w stanie go unicestwić:

Wydaje się, że trzy zmysły: wzroku, słuchu i zapachu zostały dane nam przez naturę nie po to, by informować nas o sytuacji naszych ciał, ale raczej, by określać sytuację przedmiotów zewnętrznych, które, chociaż oddalone od nas, mogą prędzej lub później oddziaływać na naszą sytuację i, w końcu, albo przynieść nam korzyść, albo krzywdę

${ }^{29}$ Tłumaczka Teorii uczuć moralnych, Danuta Petsch, nie przekładała terminu appetites w jednolity sposób, uzależniając jego tłumaczenie od kontekstu.

${ }^{30}$ A. Smith, Teoria uczuć moralnych, s. 313.

${ }^{31}$ George Berkeley początkowo posługiwał się pojęciem ,język natury”, później zastępując je określeniem ,język Stwórcy natury”, łącząc, już od wydania Nowej teorii widzenia z 1732 roku, swoją koncepcję z postrzeganiem natury jako języka, obecnym w Traktacie (por.: G. Berkeley, Próba stworzenia nowej teorii widzenia, [w:] tenże, Próba stworzenia nowej teorii widzenia i inne eseje filozoficzne, przeł. A. Grzeliński, Toruń 2011, przypis 160, s. 127). Termin „język Stwórcy natury" występuje także w drugim eseju optycznym, Berkeleya, tj. Obronie i wyjaśnieniu teorii widzenia z 1733 roku. Jak skonstatował Walter E. Creery, „Berkeley nie twierdzi, że przedmioty wzroku [...] przypominają język, ani nawet, że bardzo przypominają język, proponuje on raczej dużo mocniejszy postulat głoszący, że przedmioty wzroku są językiem" (W. E. Creery, Argument for a Divine Visual Language, „International Journal for Philosophy of Religion", vol. 3, nr 4 (zima 1972), s. 212).

${ }^{32}$ A. Smith, Of the External Senses..., $\$ 88$, s. 168, przekład własny. 
Smith poczynił przy tej okazji ciekawą obserwację: nieprzyjemne odczucia, także ból, pozwalają unikać niebezpieczeństw. Wrażenia ciepła i zimna, związane ze zmysłem dotyku, chronią, na przykład, przed poparzeniem. Gdy stają się zbyt intensywne, bolesne ${ }^{33}$, oznacza to, że wywołujący je przedmiot może zagrażać życiu lub zdrowiu. Zdaniem filozofa podążamy ku temu, co może nam przynieść zaspokojenie pragnień i potrzeb, w tym do zdobycia podstawowych rzeczy niezbędnych do przeżycia. Włączając do swoich rozważań dokonaną $\mathrm{w}$ duchu Berkeleya interpretację doświadczenia zmysłowego jako języka natury, szkocki filozof nie odbiegał daleko od własnego przekonania o tym, że ludzie mają na celu przetrwanie i działają tak, by zapewnić sobie życie wygodne, pozwalające na realizowanie też innych pragnień. W ten sposób obecne w Of the External Senses uwagi poświęcone instynktowi i popędom wpisują się w całość myśli filozofa, w której niebagatelną rolę odgrywa przeświadczenie, że człowiek pragnie własnego dobra.

Fakt ten nie oznacza jednak, że Smith przyjmował założenie o skrajnym egoizmie człowieka, ani, tym bardziej, o jego naturalnej chciwości - tę potępiał. Jego zdaniem naturalne dążenie do własnego dobra uzupełnia pragnienie szacunku i akceptacji ze strony innych, poprawy swojego losu, życia w dobrobycie, zachowania swojego istnienia - to wszystko można uzyskać dzięki pomnażaniu majątku i działaniu dla dobra własnego i najbliższych. Komentując ten aspekt koncepcji Smitha, Jerzy Chodorowski podkreślił:

... nie jest prawdą, że Smith promował egoizm rozumiany jako samolubny motyw osiągania własnych korzyści nawet poprzez narażenie innych na szkody. Nie patrzył nań tylko jak na nadużycie miłości własnej, ale dostrzegał w nim przede wszystkim nakaz religijny i moralny. Skoro bowiem człowiek ma miłować bliźniego jak siebie samego, to znaczy, że ma również miłować siebie. Ma się troszczyć o siebie, dbać o swoje życie i zdrowie, czego domaga się również przykazanie »nie zabijaj«. Dlatego w tak pojmowanej miłości własnej utrzymującej się $\mathrm{w}$ granicach moralnych widział również źródło wielu cnót. W wielu miejscach Bogactwa eksponuje tę myśl i wskazuje na dobro wynikające z miłości własnej (»egoizmu«) $)^{34}$.

Moralny nakaz troski o własne życie i dobrobyt wiąże się z naturalnymi, wrodzonymi popędami, wzmacnianymi i kształtowanymi przez doświadczenie nabywane w życiu społecznym. Autor Teorii uczuć moralnych postrzegał

\footnotetext{
${ }^{33}$ Tamże, $\$ 86$, s. 167.

${ }^{34}$ J. Chodorowski, Adam Smith, Wrocław 2002, s. 240.
} 
człowieka jako jednostkę społeczną i podkreślał rolę uczuć, więzi i relacji międzyludzkich. Jednocześnie zauważał, że w przypadku niektórych działań (w tym relacji wymiany rynkowej) odwoływanie się do interesu własnego partnerów interakcji jest najprostsze, najbardziej skuteczne i nie wymaga długotrwałego budowania więzi opartej na sympatii ${ }^{35}$. Zarazem jednak nie pochwalał łamania reguł moralnych w celu osiągnięcia indywidualnej korzyści, ponieważ realizowanie własnych celów musi być podporządkowane wymogom sprawiedliwości. Nie może być jednak uznawane za naganne moralnie: troska o siebie jest naturalną skłonnością człowieka, a roztropność (prudence) - cnotą, zalecającą dbanie o dobrą reputację i komfort życia ${ }^{36}$.

Smith podkreślał, że pragnienie samounicestwienia jest niezgodne $\mathrm{z}$ właściwie funkcjonującą - „zdrową" - naturą ludzką. Natura nigdy nie popycha człowieka ku samobójstwu, każe raczej dążyć do obrony swojego życia i dbania o nie. Mimo tego przekonania, szkocki filozof dostrzegał, że pojawiają się osoby cierpiące na depresję, czyli, jak pisał, dotknięte „melancholią, chorobą towarzyszącą „...temu, co można by nazwać nieprzezwyciężoną chęcią samozniszczenia” („an irresistible appetite for self-destruction”).

Filozof zwracał uwagę, że do odpowiedniego współodczuwania i wyrażania uczuć popycha nas nie tylko doświadczenie i wychowanie, ale też pewien rodzaj instynktu ${ }^{37}$. Mechanizm sądów moralnych opiera się nie tylko na zinternalizowanych $\mathrm{w}$ procesie socjalizacji normach i rozwijanym przez samodoskonalenie bezstronnym obserwatorze, ale także na naturalnych predyspozycjach, w które człowieka wyposażyła natura: sympatii i wyobraźni. Filozof skupiał się na niebagatelnej roli doświadczenia i wychowania ${ }^{38}$,

${ }^{35}$ J. R. Otteson, Adam Smith's Marketplace of Life, s. 150.

${ }^{36}$ A. Smith, Teoria uczuć moralnych, s. 314-415.

37 Tamże, s. 220.

${ }^{38}$ Adam Smith zwracał uwagę, że „odmienność przyrodzonych uzdolnień u różnych ludzi jest w rzeczywistości dużo mniejsza, niż nam się wydaje; a ta różnorodność uzdolnień, które, jak się zdaje, wyróżniają ludzi różnych zawodów, gdy dojdą do dojrzałości, jest w wielu wypadkach nie tyle przyczyną, ile raczej skutkiem podziału pracy. Różnica między najbardziej niepodobnymi ludźmi, na przykład między filozofem a zwykłym tragarzem zdaje się pochodzić nie tyle z natury, ile z nawyków, obyczajów i wychowania. Gdy przyszli na świat oraz w ciągu pierwszych sześciu czy ośmiu lat życia byli, być może, bardzo do siebie podobni i ani ich rodzice, ani rówieśnicy nie spostrzegli żadnych znaczniejszych między nimi różnic. W tym to mniej więcej czasie lub nieco później zaczęto ich zatrudniać w zupełnie odmiennych zajęciach. Wtedy dała się zauważyć różnica ich uzdolnień, która stopniowo wzrasta, aż wreszcie próżność filozofa nie chce już znać niemal żadnego podobieństwa do tragarza. Ale gdyby nie było skłonności do wymiany i handlu, każdy człowiek musiałby sam zdobywać sobie 
traktował je jednak również jako wzmocnienie naturalnych skłonności. Jego zdaniem, bez względu na to, czy za źródło władz moralnych uzna się rozum czy „przyrodzony instynkt zwany poczuciem moralnym” ${ }^{39}$ („original instinct, called a moral sense" ${ }^{40}$ ), to mają one kierować postępowaniem ludzkim.

Autor Teorii uczuć moralnych do naturalnych instynktów zaliczał prawo odwetu: sympatyzujemy z ofiarą przestępstwa i współodczuwamy z jej pragnieniem zemsty. Nawet w przypadku ofiar morderstwa współodczuwamy, wyobrażając sobie ich możliwe uczucia ${ }^{41}$ i odnosimy wrażenie, że należy je pomścić. Sympatyzujemy z krzywdą zamordowanego,

zdaje nam się, że jego krew głośno wzywa pomsty. Myśl, że ta krzywda miałaby pozostać niepomszczona, zdaje się naruszać spokój jego prochów. Przeraźliwa zgroza, która przypuszczalnie stale unosi się nad łożem śpiącego zabójcy, duchy, jak mówi przesąd, wstające z grobów, by szukać zemsty nad tymi, którzy doprowadzili ich do przedwczesnego końca, wszystko to pochodzi z naturalnej sympatii z rzekomym resentymentem ofiary. W ten sposób Natura, wyprzedzając późniejszą refleksję o użyteczności kary, przynajmniej jeśli chodzi o tę najstraszniejszą zbrodnię, wycisnęła w sercach ludzkich mocnymi, trwałymi znakami natychmiastową instynktowną aprobatę nienaruszalnego, nieodwołalnego prawa odwetu ${ }^{42}$.

Z drugiej strony, filozof dostrzegał, że jest coś przyjemnego w instynktownej dobrej woli ${ }^{43}$, w naturalnej życzliwości dla drugiego człowieka.

Myśliciel nie twierdził, że popędy są najważniejszą siłą decydującą o naszym zachowaniu. Wręcz przeciwnie: dominować powinny władze moralne, dające możliwość samokontroli i powściągania żądz ${ }^{44}$. Można przyjąć,

wszelkie rzeczy niezbędne do życia i służące jego wygodzie. Wszyscy musieliby spełniać te same obowiązki i wykonywać jednakową pracę i nie mogłoby być takiej różnorodności zajęć, która właśnie zrodziła tak wielką różnorodność uzdolnień" (Adam Smith, Badania nad natura i przyczynami bogactwa narodów, przeł. ks. I: S. Wolff i O. Einfeld, ks. II i III: Z. Sadowski, ks. IV: A. Prejbisz, ks V: B. Jasińska, Warszawa 2007, t. I, s. 21-22).

${ }^{39}$ A. Smith, Teoria uczuć moralnych, s. 240.

${ }^{40}$ A. Smith, The Theory of Moral Sentiments, s. 165.

${ }^{41}$ Smith dostrzegał możliwość współodczuwania zarówno ze zmarłymi, jak i z osobami nieświadomymi własnej sytuacji: chociaż one same nie są w stanie smucić się z powodu swojego stanu, nasza wyobraźnia potrafi sprawić, że stawiamy się na ich miejscu i rozważamy, co by czuli, gdyby byli w stanie.

${ }^{42}$ A. Smith, Teoria uczuć moralnych, s. 102.

${ }^{43}$ Tamże, s. 451.

${ }^{44}$ Tamże, s. 241. 
że ciała popychają nas ku określonym zachowaniom, jednakże jako istoty świadome, rozumne, społeczne i moralne jesteśmy w stanie opanować swoje pragnienia i zaspokajać je w akceptowalny sposób.

Co więcej, funkcjonowanie naturalnej dla człowieka sympatii, będącej podstawą sądów moralnych, może zostać zakłócone przez popędy. Smith zauważał, że

prawdziwą przyczyną odrazy, którą żywimy wobec pragnień cielesnych [appetites - A. M.], gdy je widzimy u innych ludzi, jest to, że nie możemy ich współdoznawać. Dla człowieka, który je odczuwa, przedmiot, który je wywołał, przestaje być przyjemny z chwilą, gdy zostały zaspokojone; nawet samo ich istnienie często staje się mu przykre ${ }^{45}$.

podobnie niewykonalne okazuje się współodczuwanie z kimś miłości, zauroczenia czy namiętności. Smith podkreślał ogromną rolę roztropności i powściągliwości oraz dostosowywania się do norm obyczajowych. Jego zdaniem kluczowa dla możliwości współodczuwania jest stosowność reakcji do wydarzeń, które ją wywołały ${ }^{46}$. Zbyt intensywna lub niewystarczająco silna reakcja może skutkować dezaprobatą. Sympatyzując, oceniamy, czy zachowanie danej osoby jest adekwatne do sytuacji. Korzystając z uczuć i rozumu, staramy się przyjąć perspektywę trzecioosobową, stawiając się na miejscu podmiotu działającego. Jednocześnie mamy zachowywać możliwie najbardziej obiektywne spojrzenie oraz wziąć pod uwagę pod uwagę okoliczności, intencje i racje stron. W ten sposób, według Smitha, powinno dokonywać się wydawanie sądów moralnych. Z czasem doskonalimy się w tym procesie i staje się on dla nas naturalny. Podobnie dzieje się, gdy oceniamy własne zachowanie - starając się zawiesić tendencję do samooszukiwania i pobudki egoistyczne, spoglądamy na własne postępowanie z perspektywy dobrze poinformowanej i możliwie najbardziej obiektywnej osoby trzeciej. Podstawą jest doświadczenie nabyte w społeczeństwie, gdy ludzie oceniają nas samych oraz innych, a my wydajemy opinie na temat ich postępowania i porównujemy je z osądami otoczenia.

Aprobata społeczna jest jednym z ważniejszych czynników motywujących ludzi do określonych działań. Smith zakładał, że każdy pragnie być szanowany, podziwiany i akceptowany. Często spoglądamy na siebie oczami innych nie tylko po to, by ocenić własne postępowanie, ale też, by rozważyć, jak je-

\footnotetext{
${ }^{45}$ A. Smith, Teoria uczuć moralnych, s. 36-37.

${ }^{46}$ S. Zabieglik, Adam Smith, Warszawa 2003, s. 45.
} 
steśmy postrzegani, co może zaważyć na ocenie własnej wartości ${ }^{47}$. Myśliciel zwrócił uwagę na swoisty instynkt dumy, który mają nawet ludzie pozbawieni odpowiednich zdolności, a który każe im zachowywać się tak, by sugerować pozycję równą innym. Takiego instynktu brakuje z kolei osobom, które autor Teorii uczuć moralnych określał mianem idiotów (ludziom o nierozwiniętych w pełni władzach umysłowych). Choć sami często uważają się za gorszych, a ich poczucie własnej wartości jest zaburzone, w rzeczywistości mogą posiadać duże umiejętności i czynić trafne spostrzeżenia ${ }^{48}$.

Filozof wspomniał również, że charakter instynktowny ma także pragnienie bycia wiarygodnym - to na nim opiera się zdolność mówienia, będąca charakterystyczna dla człowieka. Powiązał ją z chęcią rządzenia i ambicją, by panować nad innymi ${ }^{49}$. Szło to $\mathrm{w}$ parze z przekonaniem Smitha, że możnych - bogatych, wpływowych, silnych, dobrze urodzonych - szanujemy w sposób naturalny, jakkolwiek hierarchię społeczną można budować opierając się na różnych cechach. Przewagę można zdobyć dzięki sile fizycznej, szanuje się ludzi starszych, mądrzejszych. $Z$ natury podziwiamy także tych, którzy odnieśli sukces oraz dobrze urodzonych ${ }^{50}$, autor Teorii uczuć moralnych uważał, że darzymy ich naturalną sympatią. Smith za istotny motyw ludzkiego działania uznawał chęć zdobycia władzy i przewagi nad innymi: dla osiągnięcia wysokiej pozycji w hierarchii społecznej, czego można dokonać różnymi drogami: poprzez cnotliwe życie, zdobywanie majątku, arystokratyczne pochodzenie itp. ${ }^{51}$. Jak twierdził, jesteśmy w stanie poświęcić wiele i pracować z nieproporcjonalnie wielkim trudem, by osiągnąć sukces. $\mathrm{W}$ stosunku do naturalnego pragnienia panowania władza polityczna stanowi jedynie pewien jej przejaw. Przywołując jednego ze swych wielkich poprzedników, konstatował:

Bogactwo, mówi Hobbes, to władza. Lecz osoba, która zdobyła lub odziedziczyła wielki majątek, niekoniecznie zdobywa lub dziedziczy przez to jakąś władzę polityczną, cywilną lub wojskową. Majątek dać jej może środki do zdobycia jednej i drugiej, samo jednak posiadanie tego majątku niekoniecznie daje wła-

\footnotetext{
${ }^{47}$ A. Smith, Teoria uczuć moralnych, s. 269.

48 Tamże, s. 390-391.

49 Tamże, s. 269, s. 507.

${ }^{50}$ A. Smith, Badania nad natura i przyczynami bogactwa narodów, s. 365-370.

${ }^{51}$ A. Smith, Teoria uczuć moralnych, s. 89-93.
} 
dzę. Władza, jaką majątek ten daje mu natychmiast i bezpośrednio jest to siła nabywcza... ${ }^{52}$.

Chociaż wysoka pozycja społeczna, polityczna, czy ekonomiczna nie mają bezpośredniego przełożenia na uprzywilejowanie $\mathrm{w}$ pozostałych dziedzinach, to jednak mogą ułatwić osiągnięcie innych celów.

Dążenie do samozachowania jest naturalnym pragnieniem, do zaspokojenia którego konieczne jest właściwe analizowanie danych zmysłowych. Dzięki temu możliwe stanie się unikanie zagrożeń i odnajdowanie tego, co sprawia przyjemność. Uczenie się i udoskonalanie tych umiejętności jest możliwe zarówno dzięki społecznym mechanizmom uczenia się, jak i poprzez opieranie się na instynktach i popędach. Drogi te nie są sobie przeciwne, lecz nieustannie się uzupełniają. To, co wrodzone jest podstawą dla tego, co społeczne. Natomiast to, co społeczne wpływa na kształtowanie potrzeb, często „podstępem”, skłaniając do większego wysiłku owocującego rozwojem społecznym i technologicznym. To „oszustwo wyobraźni”, dzięki któremu pragniemy przedmiotów, wygód i sukcesów w rzeczywistości zbędnych do szczęśliwego życia, jak określił je Smith, przyczynia się do pomnażania dobrobytu i poprawy sytuacji ogółu ${ }^{53}$.

Sposobów zaspokajania naturalnych potrzeb uczymy się w społeczeństwie. Posługujemy się zdolnością do odczuwania. Opierając się na niej, z czasem gromadzimy doświadczenie i, na podstawie obserwacji i własnych przeżyć, uczymy się, jak skutecznie i w sposób akceptowany przez grupę zaspokajać potrzeby. Ta interesująca dynamika pomiędzy popędami i instynktami a normami społecznymi stanowi ciekawą oś interpretacyjną dla myśli Adama Smitha. Pozwala spojrzeć na jego rozważania w sposób wykraczający poza analizowanie jego poglądów ekonomicznych i etycznych.

Sięgnięcie do mniej znanych prac pozwala na ujęcie jego filozofii z szerszej perspektywy. Jednocześnie podkreślenie roli instynktów i popędów w filozofii autora Teorii uczuć moralnych zwraca uwagę, że człowiek, chociaż jest istotą społeczną, nie może przekroczyć pewnych granic, a niektóre jego zachowania opierają się na czynnikach wrodzonych, które rozwijać należy w społeczeństwie. Zarówno moralność, jak i transakcje rynkowe wynikają z naturalnych potrzeb i opierają się na wrodzonych zdolnościach - świadomość, że uwa-

\footnotetext{
${ }^{52}$ A. Smith, Badania nad natura i przyczynami bogactwa narodów, t. I, ks. I, r. 5, s. 39.

${ }^{53}$ Ch. L. Griswold, Jr, Imagination, [w:] K. Haakonssen (red.), The Cambridge Companion to Adam Smith, s. 45.
} 
runkowania biologiczne wpływają na sposób rozwijania się społeczeństwa jest niezwykle istotna dla zrozumienia myśli Adama Smitha. Moralność oraz konstrukt bezstronnego obserwatora, rozwijany przez Smitha w Teorii uczuć moralnych, tak istotny dla jego teorii moralnej, zasadza się na wrodzonych zdolnościach, za jakie można uznać sympatię i wyobraźnię. Dostrzeżenie tej zależności pozwala zrozumieć, że normy moralne, tak, jak rozumiał je Smith, nie mogą być w pełni arbitralnie ustanawiane przez otoczenie. Istnieją pewne ograniczenia wynikające $\mathrm{z}$ pewnych cech właściwych ludzkiej naturze, tym samym oczywiste staje się, że zwyczaj nie może odgrywać roli dominującej, a ogólne reguły moralności, chociaż użyteczne, mogą być kwestionowane.

Podobnie dzieje $\mathrm{z}$ wieloma innymi aspektami myśli filozofa. Również rozwój języka, handlu, kanonów piękna czy powstanie sprawiedliwości można lepiej zrozumieć, dzięki zwróceniu uwagi na czynniki wrodzone i instynktowne potrzeby. Człowiek rozwija język w społeczeństwie, jednak opiera się na wrodzonej zdolności mowy, którą wykorzystuje, by, dzięki komunikacji, zrekompensować brak samowystarczalności jednostek ludzkich i uzyskać rzeczy potrzebne do przetrwania oraz poprawy komfortu życia. Rozwój tak powstałego języka, opierającego się początkowo na prostych wyrazach, następuje jednak dopiero wśród ludzi i podlega licznym konwencjom. Odczuwamy instynktowną chęć wynagrodzenia krzywd ofiarom przestępstw. Chociaż Smith odszedł od teorii zmysłu wewnętrznego stworzonej przez Shaftesbury'ego, dostrzegał ograniczenia wpływu konwencji społecznych na postrzeganie moralności i piękna. Dlatego też pomijanie kwestii zachowań instynktownych lub motywowanych popędami nie pozwala w pełni ująć motywacji ludzkiego działania przedstawionych w najważniejszych działach Smitha - Teorii uczuć moralnych oraz Bogactwie narodów.

\section{Bibliografia}

Berkeley G., Próba stworzenia nowej teorii widzenia, [w:] Berkeley G., Próba stworzenia nowej teorii widzenia i inne eseje filozoficzne, przeł. A. Grzeliński, Toruń 2011.

Berry C., Social Theory of the Scottish Enlightenment, Edynburg 1997.

Brown K.L., Dating Adam Smith's "Of the External Senses”, „Journal of the History of Ideas”, Vol. 53, nr 2 (kwiecień - lipiec 1992).

Chodorowski J., Adam Smith, Wrocław 2002.

Creery W.E., Argument for a Divine Visual Language, „International Journal for Philosophy of Religion”, vol. 3, nr 4 (zima 1972). 
Forman-Barzilai F., Adam Smith and the Circles of Sympathy. Cosmopolitanism and Moral Theory, Cambridge 2011.

Göçmen D., The "Adam Smith Problem" and Adam Smith's Utopia, [w:] Robison W.L., Suits D.B., New Essays on Adam Smith's Moral Philosophy, Nowy Jork 2012.

Haakonssen K., Winch D., The Legacy of Adam Smith [w:] Haakonssen K. (red.), The Cambridge Companion to Adam Smith, Nowy Jork 2006.

Heath E., Mandeville's Bewitching Engine of Praise, „History of Philosophy Quarterly", Vol. 15, nr 2 (kwiecień 1998).

Hobbes T., Leviathan, http://lf-oll.s3.amazonaws.com/titles/585/Hobbes_0051-03_ EBk_v6.0.pdf, 10.05.2014.

Hobbes T., Lewiatan czyli materia, forma $i$ władza państwa kościelnego i świeckiego, przeł. C. Znamierowski, Warszawa 2009.

Hobbes T., O człowieku, [w:] Elementy filozofii, Kraków 1956.

Hobbes T., Opera Philosophica, https://archive.org/stream/operaphilosophi00mol egoog\#page/n6/mode/2up, 12.05.2014.

Hume D., O samobójstwie, [w:] Badania dotyczace rozumu ludzkiego, Kraków 2006.

Hume D., Traktat o naturze ludzkiej, Warszawa 2005.

Johnson S., A Dictionary of the English Language: in which the words are deduced from their originals, and illustrated in their different significations by examples from the best writers, Londyn 1785, t. I, https://archive.org/details/dictionaryofengl01johnuoft, 01.06.2014.

Markwart A., Szymańska M., O zmysłach i postrzeganiu - czyli czego nie wiemy o Berkeleyu, a dowiadujemy się od Smitha $i$ vice versa, „Filo-Sofija”, rok XII, nr 17 (2012/2), Bydgoszcz 2012.

McGilvary E.B., Altruism In Hume's Treatise, „The Philosophical Review”, vol. 12, nr 3, maj 1903.

Mehta P.B., Self-Interest and Other Interests, [w:] Knud Haakonssen (red.), The Cambridge Companion to Adam Smith, Londyn 2004.

Montes L., Adam Smith in Context. A Critical Reassessment of some Central Components of His Thought, 2004.

Otteson J.R., Adam Smith's Marketplace of Life, Cambridge University Press, Cambridge 2002.

Paganelli M.P., Theory of Moral Sentiments 1759 vs. Theory of Moral Sentiments 1790: a Change of Mind or a Change in Constraint? [w:] Robison W.L., Suits D.B., New Essays on Adam Smith's Moral Philosophy, Nowy Jork 2012.

Raphael D.D., Macfie A.L, Introduction [w:] A. Smith, The Theory of Moral Sentiments (red. idem), Indianapolis 1982.

Smith A., Badania nad natura i przyczynami bogactwa narodów, przeł. ks. I: S. Wolff i O. Einfeld, ks. II i III: Z. Sadowski, ks. IV: A. Prejbisz, ks V: B. Jasińska, PWN, Warszawa 2007.

Smith A., Teoria uczuć moralnych, przeł. D. Petsch, Warszawa 1989. 
Teichgraeber III R., Rethinking das Adam Smith Problem, „Journal of British Studies”, Vol. 20, nr 2 (wiosna 1981).

Thomas Reid, Rozważania o władzach poznawczych człowieka, Warszawa 1975.

Wightman W.P.D., Introduction [w:] Adam Smith, Of the External Senses, [w:] Smith A., Essays on Philosophical Subjects, 1982.

Zabieglik S., Adam Smith, Warszawa 2003.

\section{Abstract \\ Adam Smith on Instincts and Appetites}

The paper is aiming to present and analyse the notions used by Adam Smith: instinct and appetites. They appear in two of the Scottish philosopher's works: in The Theory of Moral Sentiments and in an essay Of the External Senses. Smith noticed that there are certain inborn mechanisms that suggest the existence of crucial needs and means leading to satisfy those needs. That concerns, mostly, hunger and thirst, but also sex drive (author's remarks concerning that issue turn out to be quite innovative). He regarded the need of self-preservation and of caring for one's own well-being as crucial for a man's behaviour (Smith thought that the drive towards self-destruction is unhealthy, he considered it rather as the effect of melancholy). The essay Of the External Senses mentions instinctive correlation of the objects of sight with the objects of touch as crucial for the human survival, basing on George Berkeley's theory of vision. Smith's remarks on appetites give a new perspective on how the mechanisms given us by Nature influence moral and social individuals, at the same time completing the philosopher's theory. The need to care for self's prosperity and survival can be regarded not only as an instinct, but also as actions leading to realisation of the virtue of prudence. Moreover, we learn how to fulfil our instinctive needs and appetites within the society, searching for acceptable means. In the paper Smith's view of instincts and appetites is also being briefly confronted with David Hume's and Thomas Hobbes' remarks on the subject.

Key words: Adam Smith, instinct, appetites, self-preservation, Nature 